\title{
Demystifying the link between institutional theory and stakeholder theory in sustainability reporting
}

\section{David Martin Herold}

Institute for Transport and Logistics Management (ITL),

Vienna University of Economics and Business,

Building D1, Upper level 4, Welthandelsplatz 1, 1020 Wien, Austria

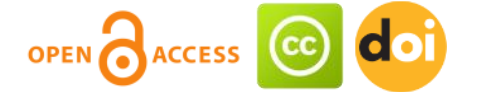

Article history:

Received: July 28, 2018

1st Revision: October 2, 2018

Accepted: October 25, 2018

JEL classification:

Q56

Q57

DOI:

10.14254/jems.2018.3-2.1
Abstract: In response to the global challenge of climate change, companies increasingly disclose sustainability-related information in form of sustainability reports. These reports, however, vary significantly due to multiple institutional and stakeholder pressures. From an academic perspective, institutional theory links these different outcomes to the influences of competing institutional logics on the field-level, representing institutional complexity on the field-level which is characterised by multiple demands from different stakeholders. Although current literature acknowledges that stakeholder may affect institutional logics, it is limited to categorise stakeholder influences on the firm-level, lacking conceptual clarity. Based on institutional and stakeholder constructs, this paper demonstrates that institutional and stakeholder theory provide, on different levels, a theoretical foundation to examine the influences on sustainability reporting. Various constructs of stakeholder theory and institutional fields as well as their limitations and further classification concepts are identified and discussed. This paper thereby advances the understanding between field-level pressures and firm-level agency and demonstrate that both theories can complement each other when examining the influences on sustainability reporting.

Keywords: sustainability reporting, stakeholder theory, institutional theory, isomorphism, organisational practices. 


\section{Introduction}

Climate change is rapidly becoming a strategic priority for companies as environmental challenges are perceived as a substantial threat to existing business models and are under scrutiny from various stakeholders (Kolk, Levy \& Pinkse, 2008). In response to these stakeholder's pressure, the disclosure of sustainability-related information about the company's activities in the form of sustainability reports has increased over the last several years (Hahn et al., 2015; KMPG, 2014). From an academic perspective, sustainability reporting can be regarded as the adoption of an organisational practice that is shaped by internal and external pressures. These pressures vary within companies and thus lead to significant variances within the associated sustainability reports (Herold \& Lee, 2018; CDP, 2014a; Scott, 1991). It is therefore of academic interest to understand what drives and influences an organisational practice such as sustainability reporting.

This paper argues that sustainability reporting is influenced by institutional as well as by stakeholders' pressures and both institutional theory and stakeholder theory provide, on different levels, a theoretical foundation to examine these influences. From an academic perspective, institutional theory links these different outcomes to the influences of competing institutional logics on the field-level, representing institutional complexity on the field-level which is characterised by multiple demands from different stakeholders. But although existing research acknowledges stakeholder may affect institutional logics, it is limited to categorise stakeholder influences on the firm-level, lacking conceptual clarity between those concepts and theories. In response, this study aims to provide a clarification on the relationship between field-level pressures and firm-level agency. At the same time, this study also aims to demonstrates that both theories, namely institutional and stakeholder theory, can complement each other while examining influences on sustainability reporting. To do so, this paper focuses on the main constructs and concepts of institutional and stakeholder theory and discusses the particular limitations of each theory in the context of sustainability reporting.

The paper is structured as follows: Section 2 provides an overview on the role of sustainability reporting. It also introduces legitimacy as rationale behind sustainability reporting. Legitimacy can be regarded as the pre-requisite of a company's 'license to operate' and represents a central thread throughout the entire paper. Section 3 begins with an overview of institutional theory and the introduction of the organisational field to further discuss homogeneity. Section 4 discuss on the main elements of heterogeneity in institutional theory, particularly on organisation's different reaction attributed to institutional complexity and competing logics. However, institutional theory is limited to categorise the salience of these actors, which leads to the introduction of stakeholder theory in section 5. The paper concludes with the limitations of stakeholder theory and introduces other theories to further examine influences on organisational practices and complement stakeholder theory.

\section{Legitimacy and the Role of Sustainability Reporting}

\subsection{Sustainability Reporting: An Overview}

Climate change is one of the biggest challenges faced by society and the business community. In response, businesses have engaged in various sustainability initiatives and communicate these activities by disclosing sustainability related information in the form of sustainability reports (Carroll \& Buchholtz, 2014; Herold and Lee, 2017a, Maditati et al., 2018, Dobrovnik et al., 2018). Sustainability reporting can be regarded as a tool to foster trust, employee loyalty and investor confidence; investors view the sustainability reporting as an indicator for the company's long-term planning and use it to assess management quality and efficiency (Schaltegger \& Csutora, 2012, Herold et al., 2016). These various external influences from a range of sources have led to an increase in corporate disclosure of information about sustainability activities (Herold and Lee, 2017b). In 2014, it is estimated that 95 per cent of the largest global 250 corporations are issuing sustainability reports compared to 64 per cent in 2005 (KMPG, 2014).

Sustainability reporting still represents a mainly voluntary organisational practice within companies (Hahn et al., 2015). Because of the mainly voluntary nature of sustainability reporting, management can choose which tools or guidelines to apply in order to measure sustainability and environmental performance. The voluntary approach of sustainability reporting may also lead to a higher information asymmetry between management and stakeholders (Sarkis et al., 2011). As the control about the information in a voluntary environment lies in general with the company's management, companies may influence the information flow to provide only selected information about their performance to stakeholders, which makes it very difficult to get insight into the 
company's activities (Kolk et al., 2008, Herold, 2018a). Therefore, sustainability reporting can be regarded as an important strategic key element for companies as it represents a channel for accountability to stakeholders. As external influences may ask to provide information for benchmarking and comparison, companies want to avoid pressure for non- or poor performance and rather be acknowledged as strong performers for reputational benefits (Fiorino, 2006, Herold and Lee, 2017c). Thus, sustainability reporting allows for a broad scope of interpretation depending on the internal and external influences.

\subsection{The Rationale behind Sustainability Reporting}

To understand the influences on sustainability reporting, the underlying rationale of sustainability reporting needs to be discussed. The most common approach in the academic community is that corporate disclosure legitimise actions by the business through a social contract where it agrees to perform various desired actions in return for approval of its objectives, other rewards and its ultimate survival (Guthrie \& Parker, 1989). Organisational legitimacy has long been acknowledged as crucial for the survival of any organisation (e.g. Dowling \& Pfeffer, 1975). Legitimacy can be defined as "a generalised perception or assumption that the actions of an entity are desirable, proper or appropriate within some socially constructed system of norms, values, beliefs and definitions" (Suchman, 1995, p.274).

As such, legitimacy can also be regarded as the underlying rationale, or the dominant motivation, for sustainability reporting (Schaltegger \& Hörisch, 2015; Windolph et al., 2014, Herold, 2018 b). To examine the legitimacy in a sustainability context, scholars usually use two theoretical lenses, namely legitimacy and institutional theory. Legitimacy theory (e.g. Suchman, 1995) offers an explanation of the motivating factors for sustainability disclosure and can be seen as a reaction to external pressure. Deegan (2002) illustrates how non-financial reporting can be used to maintain the implicit social contract between a company and society. If this contract is broken, the company may be subject to increased scrutiny (Hrasky, 2011). This is especially relevant for a topic such as climate change, which is a subject of intense public debate. However, legitimacy theory mainly explains the output of corporate sustainability disclosure (Hahn et al., 2015).

In contrast, institutional theory states that organisations are driven not merely by their aim to maximise profits, but also by the influence of different institutions (e.g., CDP, institutional investors, or governments). These expectations lead organisations to progressively adjust their behaviours (Meyer \& Rowan, 1977; Powell \& DiMaggio, 1991), hence it explains the process of or behind sustainability disclosure. Institutions represent a "web of values, norms, rules, beliefs, and taken-for-granted assumptions" (Barley and Tolbert, 1997, p.93). Instead of focusing on the utility maximization calculus of single actors, institutional theory analyses the interplay between organisations such as companies and the broader societal or organisational field in which they operate as the unit of analysis (DiMaggio \& Powell, 1983; Dowling \& Pfeffer, 1975). It distinguishes different kinds of institutions which all create implicit or explicit influences to an organisation's action (Bruton et al., 2010; Scott, 1995, 2013).

Thus, institutional theory can help us to answer questions about the influences on sustainability reporting ('how external and internal factors interactively promote organisational practices?') and different reaction to external pressures ('why do heterogeneous responses to organisational practices from institutional pressures exist?') (Sarkis et al., 2011). The following section provides an overview about institutional theory and discusses how companies seek and react to external pressures to gain legitimacy.

\section{Institutional Theory}

\subsection{Isomorphism within Institutional Theory}

At its core, institutional theory investigates the external pressures that influence the behaviour of companies to adopt certain organisational practices (Hirsch, 1975; Lai et al., 2006). Institutional scholars argue that the behaviour of companies is mainly influenced by its surrounding institutions: the cultural-cognitive, normative, and regulative structures that provided stability and collective meaning to social behaviour (Scott, 1995). In other words, institutional theory is based on the view that institutional pressures and social interactions influence the formulation of organisational actions or practices. However, more than simply suggesting that action is a reaction to external pressures, institutional theory questions the nature of social choices and asks how they are formed, mediated and channelled by the institutional environment (Wooten 
\& Hoffman, 2008). Organisational action becomes a reflection of the perspectives defined by group members comprising the institutional environment (Scott, 2001). This action, however, is not a choice among unlimited possibilities but rather represent a choice between a specific defined set of legitimate options (Wooten \& Hoffman, 2008). As an organisation is intensely aware on its dependence to the external environment, its very conception of itself changes, with consequences on many levels. When this happens, institutionalisation has set in (Selznick, 2011).

Once a social fact becomes institutionalised, it provides actors with templates for action, which creates unified or monolithic responses to gain legitimacy. For example, in response to external pressures to disclose sustainability information, companies react with the adoption of a sustainability logic. The sustainability logic becomes part of meaning system of a company and the implementation of sustainability reporting can be regarded as a expression of the sustainability logic, as it communicates sustainability values to relevant stakeholders. The main rationale behind the adoption of the logic and the reporting is to gain or maintain legitimacy, which happens through three main isomorphic mechanisms (DiMaggio \& Powell, 1983), these being:

a) coercive isomorphism,

b) mimetic processes and

c) normative pressures.

Coercive isomorphism is defined by influences carried out by those in power, e.g. through pressure from regulators and actors on which the organisation is dependent for resources. One example of coercive isomorphism is the influence of government pressures. Governments are legitimate and usually powerful stakeholders who can exert pressure through legislation, regulation and policies (Sarkis et al., 2010). Transport policy decisions, for example, are the result of the government interest in transport emissions. This pressure in form of 'authority requirements' from government organisations is often codified in laws and regulations and increasing government regulations (Summerhays \& De Villiers, 2012).

Mimetic isomorphism occurs when companies imitate competitors' behaviour. Companies may mimic or copy the actions of successful competitors to replicate their successful paths (Aerts et al., 2006). mimetic processes can be observed not only between different industries, but also in the same organisational field. Normative isomorphism can be defined as pressures arising from social institutions such as business associations, Non-Governments Organisations (NGOs) or media. International organisations or business associations such as the Sustainability Disclosure Project raise public awareness in many countries and industries worldwide (Anderies et al., 2013; CDP, 2010; CDSB, 2014). Thus, companies are under pressure to demonstrate that their organisation is a 'good citizen' and use sustainability reports to promote themselves to government and the broader community (Lee et al., 2016; Schaltegger \& Csutora, 2012).

The key message of isomorphism is that organisations with similar institutional pressures will eventually adopt similar strategies or logics to gain legitimacy. According to this traditional notion of institutional theory, the corporate disclosure behaviours of organisations should converge over time (Cormier et al., 2005; Luo et al., 2012; Matisoff et al., 2013). Hence, isomorphism in institutional theory can help to explain why companies adopt or 'institutionalise' sustainability reporting as an organisational practice.

\subsection{Limitations of Isomorphism}

Although isomorphism within institutional theory represents an essential aspect, yet the sustainability reporting of companies, even within an organisational field, varies in extent and detail (CDP, 2010). The isomorphism approach thus neglects the heterogeneity of organisational responses. Hence, isomorphism is only valid to certain extent within the field, as the depth of response to institutional pressures as well as the extensiveness of conformity varies across organisations (Scott, 2008). This important clarification leads to the conceptional adjustment, where isomorphism as the 'master hypothesis' (Hoffman \& Ventresca, 2002), is replaced by an organisational field which can be seen as dynamic or even a "field of struggles" (Bourdieu and Wacquant, 1992, p.97). In this 'field of struggles', actors are engaged in "a war or, if one prefers, a distribution of the specific capital which, accumulated in the course of previous wars, orients future strategies" (Calhoun, 1993, p.86). The organisation field becomes therefore a locale in which actors' relationships determine how the institutions and companies are influenced (Wooten and Hoffman, 2008). This results in an institutional picture of change and heterogeneity among companies as opposed to a stable and isomorphic state. 


\section{Institutional Complexity: Institutional Logics and Organisational Responses}

To further discuss the heterogeneity within institutional theory, this paper introduces the central construct of institutional theory, the 'organisational field'. In practical terms, an organisational field can represent a specific industry or a sector. According to Scott and colleagues (2000), an organisational field comprises of three constituents: (a) actors, i.e. both individuals and organisation, (b) institutional logics, i.e., the values and norms, ideas, beliefs, and meaning systems that guide the behaviour of actors, and (c) governance structures, i.e. the regulative and normative frameworks that exerts control both within individual organisations and at the wider field level.

Of particular interest for this paper is the role of institutional logics in the organisational field. Institutional logics provide organising principles for an organisational field. They are takenfor granted resilient social prescriptions that enable actors to make sense of their situation by providing "assumptions and values, usually implicit, about how to interpret organizational reality, what constitutes appropriate behaviour and how to succeed" (Thornton, 2004, p.70). Sustainability reporting is embedded in an organisational context, thus, sustainability reporting is influenced by contextual and multilevel political, cultural, and social aspects of organisational behaviour and phenomena, the so-called institutional complexity (Greenwood et al., 2010; Lounsbury \& Ventresca, 2003, Lee \& Herold, 2016).

As such, institutional complexity and the associated fight for resources and capital leads to different organisational responses. Oliver (1991) suggests that the organisational response to institutional pressures would depend on the corporation's ability to accommodate conflicting institutional demands (by renewing the enterprise strategy), to avoid the necessity of conformity (by bargaining with regulators) or to change expectations themselves (by influencing primary stakeholders in the institutional environment). The corporation's ability to accommodate, bargain or avoid compliance must rely on the use of firm-specific capabilities and the respective business strategy.

Another explanation for different organisational responses is given by Kostova and colleagues (2008), who distinguish between global operating companies and domestic firms and argue that both are substantially different from each other and it is thus impossible to achieve legitimacy through isomorphism. Fundamental to these discussions is the cross-border condition, which results in diverse, non-monolithic, fragmented, and possibly conflicting sets of external environments for global operating companies (see Lee and Herold, 2017). In addition, these companies have complex internal environments, with spatial, cultural, and organizational distance; language barriers; inter-unit power struggles; and possible inconsistencies and conflict among the interests, values, practices, and routines used in the various parts of the organisation.

Greenwood and colleagues (2010) complement this view and argue that global operating companies are embedded in multiple, fragmented, ill-defined, and constantly evolving institutional systems conceptualized at different levels of analysis, each characterized by a distinct institutional process and degree of determinism in shaping organisational behaviour. Kostova and colleagues (2008) and Van de Ven and Garud (1993) argue that the way to become legitimate in the eyes of the important legitimating actors is to negotiate this status with each of these actors, i.e. a political process of interaction, communication, and exchange, which creates a perception about the organisation without its necessarily having to implement certain models and practices.

\subsection{Competing Institutional Logics}

As discussed above, organisational responses to their contexts are unlikely to be uniform and organisational fields are usually characterized by multiple, often conflicting logics (e.g. D'Aunno et al., 1991; Hoffman, 2004; Reay \& Hinings, 2005). In this study, sustainability logic reflects the values and beliefs of a company, thus the practice of sustainability reporting is a direct consequence of the adoption of the sustainability logic. While we can acknowledge that sustainability is the logic behind the search for legitimacy, companies are also driven by the logic of the market (Greenwood et al., 2010). A market logic assumes that companies address sustainability issues (only) if this positively affects their financial performance (e.g., profits, shareholder value) (Schaltegger \& Hörisch, 2015). Managers are constantly challenged to deal with sustainability while at the same time being responsible for the well being of their organisation. While the market logic focuses on economic behaviour, i.e. to maximise profits, the sustainability logic focuses on securing legitimacy. Thus, the logics of 'market' and 'sustainability' can be considered as competing logics.

Each logic is associated with different organising principles, and each requires a different set of behaviours from actors (Schaltegger \& Hörisch, 2015). Although both logics can co-exist, but 
actors within the field will fight for a domination of 'their' preferred logic. Accordingly, powerful political contestants in the social arena will be able to have their schemas reflected within institutional logics. Essentially, those agents who are skilful in using persuasive language or rhetoric and who are sensitive to contradictions and voids can influence institutional logics (Suddaby \& Greenwood, 2005). Thus, to understand how and why organisations exhibit similarity and variation in their use of organisational practices such as sustainability reporting it is necessary to examine the relationship between the organisations' actors and their impact on practices and logics that constitute their institutional context. Nevertheless, institutional theory is limited to examine and classify these influences.

\subsection{Limitations of Institutional Theory}

Institutional theory has limitations on different levels. The traditional view of institutional theory is characterised by an isomorphic view, which is limited to explain the dynamics in the organisational field that allow for heterogeneity, variation and change (Wooten and Hoffman, 2008). More recent studies in institutional theory acknowledge that the focus on the dynamics that led to conformity in behaviour among organisations, evolved towards dynamics that allow for heterogeneity, variation and change. Heterogeneity in the field is influenced by institutional complexity, which is represented by the contextual and multiple views of actors or stakeholders (W. R. Scott, 2008). However, institutional theory is limited in its ability to explain the roles of actors with conflicting interests or is not able to provide a theoretical foundation to classify stakeholders and their degree of influence (Kostova et al., 2008).

Thus, the examination of institutional pressures is only a first step to understand the influences on organisational practices. To explain and gain a greater understanding how actors influence certain practices, there is a need to examine and analyse the roles of actors or stakeholders influencing or being influenced by an institutional logic within the organisational field. Stakeholder theory provides a theoretical foundation and mechanisms to explain or classify the type of stakeholder according to their degree of influences (Freeman, 1983). Thus, to examine the influences on an organisational practice, stakeholder theory needs to be integrated into institutional theory to classify actors or stakeholders. The following section provides an overview on stakeholder theory and its characteristics to categorise stakeholders.

\section{Stakeholder Theory and the Perception of Legitimacy}

Stakeholder theory was introduced by Freeman (1983) and showed that corporate management is influenced by a much more complex environment than simply by the concept of shareholder value. Freeman (1983) argues that the business environment is characterised by the influences of multiple stakeholders, which can be described as 'any group or individual who can affect or is affected by the achievement of an organisation's objectives' (Freeman, 1983: 46). In other words, stakeholders are those who have 'a stake' in an organisation and have something 'at risk', and they usually include internal stakeholders (managers and employees) as well as external stakeholders (shareholders, suppliers, customers, Non-Government Organisations , business associations or government authorities).

The main difference between organisations and stakeholders is their perception on legitimacy. Santana (2012) explained the assessment of a stakeholders' legitimacy is a social construction of reality. In a process that involves simplifications of a complex social context, managers are influenced by a multiple factors such as societal norms and accepted behaviours; organisational values, principles, and strategies; organisational structure of power; personal values and beliefs; and even self-serving interpretations (Gioia \& Chittipeddi, 1991; Weick, Sutcliffeand Obstfeld, 2005). As a result, the way management perceives the legitimacy of a stakeholder may or may not be in line with the stakeholder's perception of its own legitimacy.

Accordingly, organisations have to seek legitimacy from stakeholders, while stakeholders need to perceive the company's action as an accepted behaviour to legitimate the organisation (Hrasky, 2011). The main argument of stakeholder theory is that the long-term survival of the company depends on the support of these stakeholders, and a principal function of company's management is to handle the stakeholders' need and expectations as well as to balance the different interests between them. 


\subsection{Stakeholder Legitimacy in Sustainability Reporting}

The way in which companies interact with the natural environment is increasingly being seen as an important aspect of corporate legitimacy. Companies are at risk of breaching the social contract that they implicitly maintain with their stakeholders if they are perceived by those stakeholders to be acting in ways that are inconsistent with the values underpinning the contract (Deegan, 2002). Corporate activities that damage the environment or poses improper environmental risks or outcomes in the eyes of stakeholders are examples of such activities. Sustainability reporting is one way in which companies can try to convince stakeholder on their existence and their operations are legitimate (Hrasky, 2011).

As a consequence, corporate sustainability as a logic and sustainability reporting as the general approach striving for corporate sustainability challenge companies to engage with stakeholders on a multitude of contemporary social and ecological topics. The company's task is to integrate the views of stakeholders and try to balance them. On the other hand, Clarkson (1995) and Donaldson and Preston (1995) claimed that stakeholders try to incorporate their interests and be considered during the company's decision-making process. However, given the constraints imposed by the limited resources, in meeting the demands from various stakeholder, a manager may not deal with all stakeholders with the same level of importance (Chiu \& Wang, 2014). Nonetheless, gaining stakeholders' support and approval requires a dialogue between the management of a company and its stakeholders. However, the dialogue is affected by to the socalled 'information asymmetry' between management and external stakeholders, which will be explained in the next section.

\subsection{Information Asymmetry between the Organisation and Stakeholders}

Information asymmetry can be described as 'unequal dependence' between parties, e.g. between the companies' management and stakeholders (Emerson, 1962; Pfeffer, 1981). The underlying argument is that even information asymmetry is not dominated by the company's management, it will often be in management's favour (Hill and Jones, 1992). Management has the control over the decision making mechanisms within a company which puts them in a better position to exert power over stakeholders. Information asymmetry can occur in various forms: Companies may want to communicate information to external stakeholders, but may not be able to provide information as a result of a lack of full knowledge of processes within their supply chain (Sarkis et al., 2011). Moreover, given the structure of global operations, some suppliers can or do not want to provide sustainability information due to capacity or resources issues (CDP, 2014 b). Another reason is that companies may not willing to provide all information about their performance to stakeholders (Sarkis et al., 2011). Information asymmetry can also be affected by physical, cultural or social distance among supply chain partners, in particular in global supply chains (Demeter et al., 2007).

The response of stakeholders to the information asymmetry has been the development of various institutional structures for information-gathering and analysis, such as Non-Government Organisations (NGOs), business association, etc. Some of these structures have been created to consult companies in the process of collecting and analysing data (e.g. auditing firms such as KMPG, PWC, et cetera). Other structures represent non-profit or non-government organisations that exist in part to monitor the companies' actions in the interest of specific stakeholders (e.g., NGOs such as Sustainability Disclosure Project or business associations such as the World Business Council for Sustainable Development). The overall goal of these organisations is to achieve economies of scale in information gathering and analysis (Hill \& Jones, 1992).

As such, information asymmetry has a great impact on sustainability reporting, as it informs investors about the impact on environmental and social issues (Hassel et al., 2005). These investors may use their power to apply pressure on companies and call for further sustainability information. This pressure is accompanied by the benchmarking and ranking of companies by NGOs and governments. Companies may respond to these pressures by disclosing more information or by a closer relationship with relevant stakeholders (O'Dwyer, Unerman \& Hession, 2005).

However, one basic premise of stakeholder theory is that no single predominating set of interests exists between stakeholders, meaning they are diverse groups with potentially conflicting interests, power and ability to act (Savage, Dunkinand Ford, 2004). These various interests from different internal and external stakeholders are complex and stakeholder theory provides mechanisms to examine those multiple interests and relationships between stakeholders. There are several mechanisms to identify stakeholders, to investigate or categorise the stakeholder needs and interests as well as to examine the relationships between stakeholders or between a company and 
its stakeholders. The following section provides an overview over the most frequent used classification schemes.

\subsection{Mechanisms of Stakeholder Salience}

Stakeholder theory provides specific mechanisms to classify and evaluate the influences of actors. Clarkson (1995) split stakeholders into two categories: primary and secondary stakeholders. Clarkson (1995) stated that a company can not exist without gaining a support from company's primary stakeholders, who provide the infrastructure and legal frameworks in which to operate, such as shareholders, employees, customers, and suppliers. Secondary stakeholders are not considered to be crucial for the company's survival and include for example the media and special interest groups.

Mitchell and colleagues (1997) developed a frequently used framework to define the salience of stakeholders' relations that has since been regularly used by practitioners and researchers alike. They argue that stakeholder identification and salience are a function of the stakeholder possessing one or more of the three relationship attributes: (1) the stakeholder's power to influence the firm, (2) the legitimacy of the stakeholder's relationship with the firm, and (3) the urgency of the stakeholder's claim on the firm.

Power refers to the stakeholders that control critical resources for the company, which means that these stakeholders have the access or power to material or financial resources to enforce its will within the relationship. For the second factor, stakeholders achieve legitimacy if they have legitimate claims on the company, where the basis of the legitimacy of the relationship may derive from contract, exchange, legal or moral right, legal title, or at-risk status (Hill and Jones, 1992). However, a legitimate claim only be regarded as salient, if the stakeholder has the power to impose its will or if the claim is perceived as urgent. Hence, the third factor, urgency, is related to the level of importance and attention attributed to the claim. Mitchell et al. (1997) characterise this factor by time sensitivity (the claims needing to be given immediate attention) and necessity (the claims being vital and highly important). The different combinations of these three attributes (power, legitimacy, urgency) resulted in a categorisation of seven stakeholder types by Mitchell et al. (1997).

Preble (2005) introduced a comprehensive stakeholder management process model with the aim to provide a platform to facilitate stakeholder management practices within organisations. This six-step process is supposed to be applied to an company's business and contains a several mechanisms to categorise stakeholders, including the processes of Clarkson (1995) and Mitchell and colleagues (1997). Friedman and Miles (2006) developed another popular framework to categorise or rank stakeholder influences. They theorise that the different styles of dialogue of stakeholders with organisations indicate the level of power and involvement of stakeholders. The lowest level of power is characterised by non-participation, while the highest level represents a multi-way dialogue of stakeholders with a major influence of the company's decision process. In other words, the higher the rank, the higher the interdependency and the collaboration with stakeholders. These different mechanisms to identify and classify stakeholders can be regarded as a first step to provide a theoretical foundation to investigate why actors within a field chose different approaches in sustainability reporting.

\subsection{Limitations of Stakeholder Theory and further Classification Concepts}

Stakeholder mechanisms only examines a fragment of the multidimensionality of the stakeholder, thus overlooking others. In other words, the current stakeholder categorisation mechanisms can be seen as mono-dimensional and inadequate to create a complex, multidimensional picture of stakeholders (Bryson et al., 2011; Reed et al., 2009). Ribeiro and colleagues (2011) argue that the existing stakeholder management processes is insufficient to describe the holistic and multi-way relationships between stakeholders and the company's management.

In terms of a network perspective, stakeholder theory has limitations to explain the dynamics of power relationships between stakeholders or between companies and its stakeholders. However, the role of power in stakeholder relationships should not be underestimated, as power of certain stakeholder groups can constitute an institutional factor (e.g. by creating a powerful NGO) that can influence the organisational practice and even an organisational field. Hence, the analysis of stakeholder networks is critical in order to understand, for example, stakeholder alliances and their influence.

To complement stakeholder theory in this context, network theory provides a suitable answer. Network theory describes the processes and mechanisms of interactions within a network 
structure to generate insight about the relationships of groups or individuals in this network. Within network theory, Social Network Analysis (SNA) can provide important indications for stakeholder identification and can be used to categorise stakeholder (Prell et al., 2009; Reed et al., 2009; Sedereviciute \& Valentini, 2011). SNA can complements stakeholder analysis (Holland, 2007) and begins "where stakeholder research stops and examines systems of dyadic interactions, capturing the influence of multiple and interdependent relationships of an organisations' behaviour" (Rowley, 1997, p.894). Furthermore, although stakeholder salience can assist to identify who are the important stakeholders, it provides only little insight why they are stakeholders and more importantly, how they influence sustainability reporting. To overcome this limitation, Hill and Jones (1992) introduced the stakeholder-agency theory to understand these processes. The main construct if stakeholder agency theory are 'power differentials' between parties. Power differentials relate to the information asymmetry between between the companies' management and stakeholders outside the company. Both theories, network as well as stakeholder-agency theory, provide an extension to stakeholder theory that can be used contextually to examine stakeholders' influences.

\section{Conclusion}

The aim of this paper was to examine the link between institutional theory and stakeholder theory in the context of sustainability reporting. There are three main conclusions that can be drawn. First, institutional theory provides good explanations for the adoption of sustainability reporting. In particular, the paper discussed the adoption of the sustainability logic and the organisational practice of sustainability reporting through the three mechanisms of coercive isomorphism, mimetic processes and normative pressures. While isomorphic behaviour indicates that organisational practices become the same over time, in particular in an organisational field, it is limited to explain the diversity in field. In practical terms, it can be expected that isomorphism leads to very similar sustainability reporting, in particular in the same industry, but this is not the case. As sustainability reporting varies, isomorphism is limited to explain these differences and the heterogeneity in the field.

Second, the role of different institutional contexts (or institutional complexity) in determining how organisations respond to institutional pressures for sustainability was discussed. The paper highlights the corporate strategic response as well as the fight for a dominant logic which can be attributed to the complexity of contextual factors. The core of these management decisions within the institutional complexity are the dynamics and multiple interests of actors in the field. These dynamics of the relationship between stakeholders or actors represent not only a constant fight for influence between the company's management and stakeholders outside the company, but also a 'field of struggles' between actors within the organisational field, thereby linking field-level pressures and firm-level agency.

Third, linking stakeholder and institutional theory emphasises the critical role of actors or stakeholders and how these actors or stakeholders and their relationships can influence the relative importance of institutional logics and thus the degree of sustainability reporting. As such, this paper demonstrated that stakeholder theory can complement institutional theory to identify and investigate the respective roles of stakeholders and actors and their degree of influence in the field.

\section{Appendix A. Supplementary material}

Supplementary data associated with this article can be found, in the online version, at https://doi.org/10.14254/jems.2018.3-2.1

\section{Funding}

The authors received no direct funding for this research.

\section{Citation information}

Herold, M. H. (2018). Demystifying the link between institutional theory and stakeholder theory in sustainability reporting. Economics, Management and Sustainability, 3(2), 6-19. doi:10.14254/jems.2018.3-2.1. 


\section{References}

Aerts, W., Cormier, D., \& Magnan, M. (2006). Intra-industry imitation in corporate environmental reporting: An international perspective. Journal of Accounting and Public Policy, 25(3), 299331.

Anderies, J. M, Folke, C., Walker, B., \& Ostrom, E. (2013). Aligning key concepts for global change policy: Robustness, resilience, and sustainability. Ecology and Society, 18(2), 26-41.

Barley, S. R., \& Tolbert, P. S. (1997). Institutionalization and structuration: Studying the links between action and institution. Organization Studies, 18(1), 93-117.

Bourdieu, P., \& Wacquant, L. (1992). An Invitation towards a Reflexive Sociology. Cambridge, UK: Policy Press.

Bruton, G. D, Ahlstrom, D., \& Li, H.-L. (2010). Institutional theory and entrepreneurship: where are we now and where do we need to move in the future?. Entrepreneurship Theory and Practice, 34(3), 421-440.

Bryson, J. M., Patton, M. Q. \& Bowman, R. A. (2011). Working with evaluation stakeholders: A rationale, step-wise approach and toolkit. Evaluation and Program Planning, 34(1), 1-12.

Calhoun, C. (1993). Nationalism and ethnicity. Annual Review of Sociology, 19, 211-239.

Carroll, A. \& Buchholtz, A. (2014). Business and Society: Ethics, Sustainability, and Stakeholder Management: Cengage Learning.

CDP. (2010). Transport Report. Retrieved from London: https://www.cdp.net/CDPResults/CDPTransport-Report.pdf

CDP. (2014a). Sustainability Disclosure Project (2014). Retrieved from http://www.cdproject.net/index.asp

CDP. (2014b). Investor CDP 2014 Information Request - FedEx Corporation. Retrieved from London:

CDSB. (2014). Climate Disclosure Standards Board. Retrieved from http://www.cdsb-global.org/

Chiu, T.-K., \& Wang, Y.-H. (2014). Determinants of social disclosure quality in Taiwan: An application of stakeholder theory. Journal of Business Ethics, 1-20.

Clarkson, M. E. (1995). A stakeholder framework for analyzing and evaluating corporate social performance. Academy of Management Review, 20(1), 92-117.

Cormier, D., Magnan, M., \& Van Velthoven, B. (2005). Environmental disclosure quality: Do firms respond to economic incentives, public pressures or institutional conditions. European Accounting Review, 14(1), 1-37.

D'Aunno, T., Sutton, R.I., \& Price, R. H. (1991). Isomorphism and external support in conflicting institutional environments: A study of drug abuse treatment units. Academy of Management Journal, 34(3), 636-661.

Deegan, C. (2002). Introduction: The legitimising effect of social and environmental disclosures: A theoretical foundation. Accounting, Auditing and Accountability Journal, 15(3), 282-311.

Demeter, K., Simpson, D., Power, D., \& Samson, D. (2007). Greening the automotive supply chain: A relationship perspective. International Journal of Operations and Production Management, $27(1), 28-48$.

DiMaggio, P. J., \& Powell, W. W. (1983). The Iron Cage Revisited: Institutional isomorphism and collective rationality in organizational fields. American Sociological Review, 48(2), 147-160.

Dobrovnik, M., Herold, D.M., Fürst, E., \& Kummer, S. (2018). Blockchain for and in Logistics: What to Adopt and Where to Start. Logistics, 2(3), 18.

Donaldson, T., \& Preston, L. E. (1995). The stakeholder theory of the corporation: Concepts, evidence, and implications. Academy of Management Review, 20(1), 65-91.

Dowling, J., \& Pfeffer, J. (1975). Organizational legitimacy: Social values and organizational behavior. Pacific Sociological Review, 122-136.

Emerson, R. M. (1962). Power-dependence relations. American Sociological Review, 31-41.

Fiorino, D. J. (2006). The new environmental regulation: Mit Press. 
Freeman, R. E. (1983). Strategic management: A stakeholder approach. Advances in Strategic Management, 1(1), 31-60.

Friedman, A. L., \& Miles, S. (2006). Stakeholders: Theory and practice. Oxford: Oxford University Press.

Gioia, D. A., \& Chittipeddi, K. (1991). Sensemaking and sensegiving in strategic change initiation. Strategic Management Journal, 12(6), 433-448.

Greenwood, R., Díaz, A. M., Li, S. X., \& Lorente, J. C. (2010). The multiplicity of institutional logics and the heterogeneity of organizational responses. Organization Science, 21(2), 521-539.

Guthrie, J., \& Parker, L. D. (1989). Corporate social reporting: a rebuttal of legitimacy theory. Accounting and Business Research, 19(76), 343-352.

Hahn, R., Reimsbach, D., \& Schiemann, F. (2015). Organizations, climate change, and transparency: Reviewing the literature on Sustainability Disclosure. Organization and Environment, 28(1), 80-102.

Hassel, L., Nilsson, H., \& Nyquist, S. (2005). The value relevance of environmental performance. European Accounting Review, 14(1), 41-61.

Herold, D. M. (2018a). Has carbon disclosure become more transparent in the global logistics industry? An investigation of corporate carbon disclosure strategies between 2010 and 2015. Logistics, 2(3), 13.

Herold, D.M. (2018b). The Influence of Institutional and Stakeholder Pressures on Carbon Disclosure Strategies: An Investigation in the Global Logistics Industry, Doctoral dissertation, Griffith University.

Herold, D. M., \& Lee, K.-H. (2017a). Carbon management in the logistics and transportation sector: An overview and new research directions. Carbon Management, 8(1), 79-97.

Herold, D. M., \& Lee, K.-H. (2017b). The Influence of the Sustainability Logic on Carbon Disclosure in the Global Logistics Industry: The Case of DHL, FDX and UPS. Sustainability, 9(4), 601.

Herold, D.M., \& Lee, K.H. (2017c). Corporate environmental responsibility: focus, orientation and significance in the natural resources sector. International Journal of Global Environmental Issues, 16(4), 254-276.

Herold, D. M., \& Lee, K.-H. (2018). Carbon Disclosure Strategies in the Global Logistics Industry: Similarities and Differences in Carbon Measurement and Reporting. In M. Hossain, R. Halesand T. Sarker (Eds.), Pathways to a Sustainable Economy : Bridging the Gap between Paris Climate Change Commitments and Net Zero Emissions (pp. 87-101). Cham: Springer International Publishing.

Herold, D. M., Manwa, F., Sen, S., \& Wilde, S. J. (2016). It's the yeast we can do: Untapping Sustainability Trends in Australian Craft Breweries. Journal of Asia Entrepreneurship and Sustainability, 12(2), 82-110.

Hill, C. W. L., \& Jones, T. M. (1992). Stakeholder-agency theory. Journal of Management Studies, 29(2), 131-154.

Hirsch, P. M. (1975). Organizational effectiveness and the institutional environment. Administrative Science Quarterly, 20(3), 327-344.

Hoffman, A. J., \& Ventresca, M. J. (2002). Organizations, policy and the natural environment: Institutional and strategic perspectives: Stanford University Press.

Hoffman, A. J. (2004). Climate change strategy: The business logic behind voluntary greenhouse gas reductions. Ross School of Business Paper.

Holland, J. (2007). Tools for institutional, political, and social analysis of policy reform: a sourcebook for development practitioners. Retrieved from Washinton, D.C.:

Hrasky, S. (2011). Sustainability footprints and legitimation strategies: symbolism or action? Accounting, Auditing and Accountability Journal, 25(1), 174-198.

KMPG. (2014). Corporate sustainability. A progress report. Retrieved from: http://www.kpmg.com/Global/en/IssuesAndInsights/ArticlesPublications/Documents/cor porate-sustainability-v2.pdf 
Kolk, A., Levy, D., \& Pinkse, J. (2008). Corporate responses in an emerging climate regime: the institutionalization and commensuration of sustainability disclosure. European Accounting Review, 17(4), 719-745.

Kostova, T., Roth, K., \& Dacin, M. T. (2008). Institutional theory in the study of multinational corporations: A critique and new directions. Academy of Management Review, 33(4), 9941006.

Lai, K.-H., Wong, C. W. Y., \& Cheng, T. C. E. (2006). Institutional isomorphism and the adoption of information technology for supply chain management. Computers in Industry, 57(1), 93-98.

Lee, K.-H., \& Herold, D. M. (2016). Cultural relevance in corporate sustainability management: a comparison between Korea and Japan. Asian Journal of Sustainability and Social Responsibility, 1-21.

Lee, K.-H., Herold, D. M., \& Yu, A. (2016). Small and Medium Enterprises and Corporate Social Responsibility Practice: A Swedish Perspective. Corporate Social Responsibility and Environmental Management, 23(2), 88-99.

Lee, K.H., \& Herold, D.M. (2017), Cultural Relevance in Environmental and Sustainability Management Accounting in the Asia-Pacific region: A link between cultural values and accounting values towards EMA values. In: Lee, K.H. and Schaltegger, S. (eds), Accounting for Sustainability: Asia Pacific Perspectives (pp.11-37). Cham: Springer International Publishing.

Lounsbury, M., \& Ventresca, M. (2003). The new structuralism in organizational theory. Organization, 10(3), 457-480.

Luo, L., Lan, Y.-C., \& Tang, Q. (2012). Corporate incentives to disclose sustainability information: Evidence from the CDP Global 500 Report. Journal of International Financial Management and Accounting, 23(2), 93-120.

Maditati, D. R., Munim, Z. H., Schramm, H. J., \& Kummer, S. (2018). A review of green supply chain management: From bibliometric analysis to a conceptual framework and future research directions. Resources, Conservation and Recycling, 139, 150-162.

Matisoff, D. C., Noonan, D. S., \& O'Brien, J. J. (2013). Convergence in environmental reporting: assessing the Sustainability Disclosure Project. Business Strategy and the Environment, 22(5), 285-305.

Meyer, J. W., \& Rowan, B. (1977). Institutionalized organizations: Formal structure as myth and ceremony. American Journal of Sociology, 83(2), 340-363.

Mitchell, R. K., Agle, B. R., \& Wood, D. J. (1997). Toward a theory of stakeholder identification and salience: Defining the principle of who and what really counts. Academy of Management Review, 22(4), 853-886.

O'Dwyer, B., Unerman, J., \& Hession, E. (2005). User needs in sustainability reporting: Perspectives of stakeholders in Ireland. European Accounting Review, 14(4), 759-787.

Oliver, C. (1991). Strategic responses to institutional processes. Academy of Management Review, 16(1), 145-179.

Pfeffer, J. (1981). Power in organizations. Marshfield, MA: Pitman.

Powell, W. W., \& DiMaggio, P. J. (1991). The new institutionalism in organizational analysis. Chicago, IL: University of Chicago Press.

Preble, J. F. (2005). Toward a comprehensive model of stakeholder management. Business and Society Review, 110(4), 407-431.

Prell, C., Hubacek, K., \& Reed, M. (2009). Stakeholder analysis and social network analysis in natural resource management. Society and Natural Resources, 22(6), 501-518.

Reay, T., \& Hinings, C. R. B. (2005). The recomposition of an organizational field: Health care in Alberta. Organization Studies, 26(3), 351-384.

Reed, M. S., Graves, A., Dandy, N., Posthumus, H., Hubacek, K., Morris, J., \& Stringer, L. C. (2009). Who's in and why? A typology of stakeholder analysis methods for natural resource management. Journal of Environmental Management, 90(5), 1933-1949.

Ribeiro Soriano, D., Peris-Ortiz, M., Wagner Mainardes, E., Alves, H., \& Raposo, M. (2011). Stakeholder theory: Issues to resolve. Management Decision, 49(2), 226-252. 
Rowley, T. J. (1997). Moving beyond dyadic ties: A network theory of stakeholder influences. Academy of Management Review, 22(4), 887-910.

Santana, A. (2012). Three elements of stakeholder legitimacy. Journal of Business Ethics, 105(2), 257-265.

Sarkis, J., Gonzalez-Torre, P., \& Adenso-Diaz, B. (2010). Stakeholder pressure and the adoption of environmental practices: The mediating effect of training. Journal of Operations Management, 28(2), 163-176.

Sarkis, J., Zhu, Q., \& Lai, K.-H. (2011). An organizational theoretic review of green supply chain management literature. International Journal of Production Economics, 130(1), 1-15.

Savage, G. T., Dunkin, J. W., \& Ford, D. M. (2004). Responding to a crisis: A stakeholder analysis of community health organizations. Journal of Health and Human Services Administration, $26(3 / 4), 383-414$.

Schaltegger, S., \& Csutora, M. (2012). Sustainability accounting for sustainability and management. Status quo and challenges. Journal of Cleaner Production, 36, 1-16.

Schaltegger, S., \& Hörisch, J. (2015). In search of the dominant rationale in sustainability management: Legitimacy-or profit-seeking? Journal of Business Ethics, 1-18. doi:10.1007/s10551-015-2854-3

Scott, W. R. (2001). Institutions and Organizations. Thousand Oaks, CA: Sage.

Scott, W. R. (1991). Unpacking institutional arguments. In Walter W Powell and Paul J DiMaggio (Eds.), The new institutionalism in organizational analysis (pp. 164-182). Chicago: University of Chicago Press.

Scott, W. R. (1995). Institutions and organizations: Foundations for organizational science. London: Sage.

Scott, W. R. (2008). Approaching adulthood: The maturing of institutional theory. Theory and Society, 37(5), 427-442.

Scott, W. R. (2013). Institutions and organizations: Ideas, interests, and identities. Thousand Oaks, CA: Sage.

Scott, W. R., Ruef, M., Mendel, P. J., \& Caronna, C. A. (2000). Institutional change and healthcare organizations: From professional dominance to managed care. Chicago, IL: University of Chicago Press.

Sedereviciute, K., \& Valentini, C. (2011). Towards a more holistic stakeholder analysis approach: Mapping known and undiscovered stakeholders from social media. International Journal of Strategic Communication, 5(4), 221-239.

Selznick, P. (2011). Leadership in administration: A sociological interpretation: Quid Pro Books.

Suchman, M. C. (1995). Managing legitimacy: Strategic and institutional approaches. Academy of Management Review, 20(3), 571-610.

Suddaby, R., \& Greenwood, R. (2005). Rhetorical strategies of legitimacy. Administrative Science Quarterly, 50(1), 35-67.

Summerhays, K., \& De Villiers, C. J. (2012). Oil company annual report disclosure responses to the 2010 Gulf of Mexico oil spill. Journal of the Asia-Pacific Centre for Environmental Accountability, 18(2), 103-130.

Thornton, P. H. (2004). Markets from culture: Institutional logics and organizational decisions in higher education publishing. Standford, CA: Stanford University Press.

Thornton, P. H., Ocasio, W., \& Lounsbury, M. (2012). The institutional logics perspective: A new approach to culture, structure, and process: Oxford University Press.

Van de Ven, A. H., \& Garud, R. (1993). Innovation and industry development: The case ofcochlear implants. Research on Technologicalinnovation, Management and Policy, 5, 1-46.

Weick, K. E., Sutcliffe, K. M., \& Obstfeld, D. (2005). Organizing and the process of sensemaking. Organization Science, 16(4), 409-421. 
Windolph, S. E., Harms, D., \& Schaltegger, S. (2014). Motivations for corporate sustainability management: contrasting survey results and implementation. Corporate Social Responsibility and Environmental Management, 21(5), 272-285.

Wooten, M., \& Hoffman, A. J. (2008). Organizational fields: Past, present and future. In Royston Greenwood, Christine Oliver, K. Shalin-Anderssonand Roy Suddaby (Eds.), The Sage Handbook of Organizational Institutionalism (pp. 130-147). London: Sage.

Xu, D., \& Shenkar, O. (2002). Institutional distance and the multinational enterprise. Academy of Management Review, 27(4), 608-618.

Zucker, L. G. (1977). The role of institutionalization in cultural persistence. American Sociological Review, 42, 726-743.

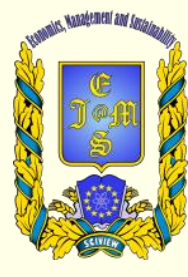

(c) 2016-2018, Economics, Management and Sustainability. All rights reserved.

This open access article is distributed under a Creative Commons Attribution (CC-BY) 4.0 license.

You are free to:

Share - copy and redistribute the material in any medium or format Adapt - remix, transform, and build upon the material for any purpose, even commercially.

The licensor cannot revoke these freedoms as long as you follow the license terms.

Under the following terms:

Attribution - You must give appropriate credit, provide a link to the license, and indicate if changes were made.

You may do so in any reasonable manner, but not in any way that suggests the licensor endorses you or your use.

No additional restrictions

You may not apply legal terms or technological measures that legally restrict others from doing anything the license permits.

Economics, Management and Sustainability (ISSN: 2520-6303) is published by Scientific Publishing House "CSR", Poland, EU and Scientific Publishing House "SciView", Poland

Publishing with JEMS ensures:

- Immediate, universal access to your article on publication

- High visibility and discoverability via the JEMS website

- Rapid publication

- Guaranteed legacy preservation of your article

- Discounts and waivers for authors in developing regions

Submit your manuscript to a JEMS at http://jems.sciview.net or submit.jems@sciview.net

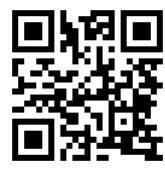

